\title{
Benthic estuarine communities in Brazil: moving forward to long term studies to assess climate change impacts
}

\author{
Angelo Fraga Bernardino ${ }^{1, *}$, Paulo Roberto Pagliosa ${ }^{2}$, Ronaldo Adriano Christofoletti ${ }^{3}$, Francisco \\ Barros $^{4}$, Sergio A. Netto ${ }^{5}$, Pablo Muniz ${ }^{6}$, Paulo da Cunha Lana
}

\author{
${ }^{1}$ Departamento de Oceanografia e Ecologia, CCHN, Universidade Federal do Espírito Santo. \\ (Av. Fernando Ferrari, 514, Goiabeiras, Vitória - ES, CEP: 29075-910, Brasil) \\ ${ }^{2}$ Universidade Federal de Santa Catarina, CFH, Departamento de Geociências, Laboratório de Biodiversidade e Conservação Marinha. \\ (CEP: 88040-900, Florianópolis - SC, Brasil) \\ ${ }^{3}$ Instituto do Mar, Universidade Federal de São Paulo. \\ (Av. Alm. Saldanha da Gama 89, Ponta da Praia, Santos, SP, CEP: 11030-400, Brazil) \\ ${ }^{4}$ Laboratório de Ecologia Bentônica, Instituto de Biologia, Universidade Federal da Bahia. \\ (Rua Barão de Jeremoabo s/n.,Ondina, Salvador, CEP: 40170-115, Tel: (71) 3283-6552) \\ ${ }^{5}$ Laboratório de Ciências Marinhas, Universidade do Sul de Santa Catarina. \\ (Av. Acácio Moreira ,787, Dehon, Tubarão, SC, CEP: 88704-900) \\ ${ }^{6}$ Oceanografia y Ecologia Marina, Instituto de Ecología y Ciencias Ambientales (IECA), Facultad de Ciencias, Universidad de la República. \\ (Iguá 4225, Montevideo, 11400, Uruguay) \\ ${ }^{7}$ Centro de Estudos do Mar, Universidade Federal do Paraná. \\ (CEP: 83255-979, Pontal do Sul, Paraná, Brazil)
}

*Corresponding author: angelofraga@gmail.com

\section{Abstract}

Estuaries are unique coastal ecosystems that sustain and provide essential ecological services for mankind. Estuarine ecosystems include a variety of habitats with their own sediment-fauna dynamics, all of them globally undergoing alteration or threatened by human activities. Mangrove forests, saltmarshes, tidal flats and other confined estuarine systems are under increasing stress due to human activities leading to habitat and species loss. Combined changes in estuarine hydromorphology and in climate pose severe threats to estuarine ecosystems on a global scale. The ReBentos network is the first integrated attempt in Brazil to monitor estuarine changes in the long term to detect and assess the effects of global warming. This paper is an initial effort of ReBentos to review current knowledge on benthic estuarine ecology in Brazil. We herein present and synthesize all published work on Brazilian estuaries that has focused on the description of benthic communities and related ecological processes. We then use current data on Brazilian estuaries and present recommendations for future studies to address climate change effects, suggesting trends for possible future research and stressing the need for long-term datasets and international partnerships.

Descriptors: Estuaries, Benthic ecology, Climate change, Brazil, Impacts

\section{RESUMO}

Estuários são ecossistemas costeiros que sustentam uma ampla variedade de serviços ambientais para a humanidade. Estuários abrigam muitos ambientes bentônicos com características específicas e seriamente ameaçados globalmente. Manguezais, marismas e planícies de maré são amplamente impactados por poluentes domésticos e industriais, por atividades comerciais que levam à perda de habitat e pela sobrepesca. Os diversos impactos locais, associados a mudanças regionais e globais na hidromorfologia estuarina e potenciais efeitos de mudanças climáticas, colocam sérias ameaças a ecossistemas estuarinos. A rede Bentos foi criada para estudar o efeito de mudanças no clima em ecossistemas bentônicos costeiros brasileiros. Este trabalho faz parte dos esforços iniciais do Grupo de Trabalho Estuários em rever o conhecimento sobre comunidades bentônicas estuarinas no Brasil. Aqui apresentamos uma breve revisão crítica sobre os trabalhos realizados objetivando o estudo, em nível de comunidades, do bentos estuarino e processos ecológicos associados. A partir do cenário atual, realizamos recomendações de estudo para responder questões científicas sobre efeitos de mudanças climáticas em comunidades bentônicas estuarinas, e enfatizamos a necessidade de bases de dados contínuas e de longa duração e o estabelecimento de parcerias internacionais com foco específico nos estuários brasileiros.

Descritores: Estuários, Ecologia bêntica, Mudança climática, Brasil, Impactos 


\section{INTRODUCTION}

Estuarine benthic ecosystems are heterogeneous systems that provide highly diverse habitats and their biological assemblages are frequently used as indicators of natural and anthropogenic changes. The spatial and temporal variability of estuarine populations and communities are largely conditioned by climate, runoff regimes and oceanic dynamics, through changes in nutrients, primary production and sediments (MALLIN et al., 1993; HEIP et al., 1995). Thus estuarine fauna must be highly adapted to deterministic and stochastic environmental changes (ELLIOTT and QUINTINO, 2007) which may occur on a local, regional or global scale. Local and regional changes may be linked to the relative dominance of riverine, wave or tidal processes directly affecting habitat diversity and spatial and temporal gradients in sediments and organic matter.

Brazil has a long coastline with over one hundred estuaries from the tropical equator in the North to due to regions in the South. Brazilian estuaries differ widely in their tidal regimes (e.g. from macrotidal on the northern to microtidal on the southeastern and southern coasts), input of run-off discharges (i.e., higher average rainfall in the northern and southern regions) and wave action. Geomorphological differences are also main causes of dissimilarities among Brazilian estuaries (DOMINGUEZ, 2006). Estuaries dominated by riverine inputs are more frequent in the $\mathrm{N}$ and $\mathrm{NE}$ and within bays, and drowned estuaries and lagoons are more common in the SE and S. Macroscale changes associated with large-scale environmental differences in Brazilian estuaries may be due to atmospheric, oceanographic and climate variability, as well as to local or regional human activities. Global climate dynamics could, therefore, act directly upon local estuarine benthic populations or promote cross-scale interactions influencing species responses on both local and regional scales.

Estuaries have been intensely modified over recent decades by human activities. Sewage outfalls and eutrophication, habitat loss, overfishing and several hydrodynamic changes have produced marked impacts worldwide (NORKKO et al., 2002; SCAVIA et al., 2002). Brazilian estuaries are no exception and several studies have reported multiple human impacts near large urban areas (SANTI and TAVARES, 2009; SOARES-GOMES et al., 2012; KRULL et al., 2014). It is widely accepted that potential effects of climate change will further impact estuarine communities by changes in average temperature, in yearly rainfall and in mean sea level (ATTRILL and POWER, 2000; NAJJAR et al., 2000; GILLANDERS and KINGSFORD, 2002). However, it is still extremely difficult to predict the intensity and scale of these changes and the response of biological communities and changes in ecosystem functioning. Temperature and rainfall anomalies, as well as sea level rise, have been commonly reported across the globe and these effects may have substantial impacts on estuarine ecosystems over both the short- and long-term (ALONGI, 2008; DAY et al., 2008; CONDIE et al., 2012; TURRA et al., 2013; GARCÍARODRIGUEZ ET AL., 2014). For example, if regional and local rainfall anomalies and sea level changes alter the salt balance of an estuary, it might cause changes in species distribution and productivity (THURMAN et al., 2010; CONDIE et al., 2012). Higher temperatures could also affect the metabolism, growth and reproduction of estuarine biota, which combined with local eutrophication may lead to oxygen depletion and mass mortality of organisms (BISHOP et al., 2006). It is expected that the intensity of impacts and ecological effects of climate change on estuaries will be site-specific. However, long-term changes in climate may also alter estuarine communities and ecosystem resilience on larger scales that are relevant to ecosystem management and function (DOLBETH et al., 2011; ELLIOTT and WHITFIELD, 2011; MCLEOD et al., 2011).

Projected changes in global climate are the greatest current threat to ecological function and the associated socio-economic services provided to mankind (ANTLE et al., 2001; DONEY et al., 2012; TURRA et al., 2013). As such, the major challenge to modern ecology is to understand and to predict how climate change will translate into ecological impacts and affect human well-being. To scientifically assess changes in estuarine ecosystems and promote their long-term conservation and management, we have created "The Monitoring Network for Coastal Benthic Habitats" (ReBentos - Working group on Estuaries), an integrated effort on the part of researchers and institutions along Brazil's 8,000 km of coast line. ReBentos's main goals are to establish long-term observations of benthic estuarine communities and other coastal ecosystems, through sound scientific practices to detect and assess the effects of climate change. The ReBentos Estuaries working group's assignment is to develop studies using the estuarine benthic fauna as a biological model for climate change assessment. Benthic ecosystems are particularly useful to understand how estuaries will be affected by climate change because 
they are the key to many biogeochemical and ecological processes at the sediment water interface (SMITH et al., 2000; KRISTENSEN et al., 2008). Benthic communities are also overwhelmingly used as indicators of the biotic quality of estuarine ecosystems, and thus the ReBentos project's efforts qualify it for inclusion among several international programs with similar goals (e.g. Climate Ready Estuaries - EPA/USA; Marbef network program - EU).

In order to design and propose a long-term monitoring program, we have carried out an exhaustive synthesis of published work on the benthic communities of estuarine ecosystems in Brazil and have assessed their vulnerability to past and current changes in temperature and rainfall (BERNARDINO et al., 2015a). These theoretical predictions may be useful to address site-specific vulnerabilities in several Brazilian estuaries to projected climate change and result in mitigation and adaptation on a regional scale. The ReBentos network has proposed several protocols to standardize historical time series data acquisition on benthic estuarine ecosystems across Brazil. In order to suggest best scientific practices for long-term monitoring of benthic ecosystems, this paper: i) critically reviews the published work on estuarine benthic invertebrates along the Brazilian coast in respect to their usefulness as baselines for climate change studies; ii) suggests a long-term sampling protocol using benthic communities as models for climate-related impacts in estuaries, and iii) compares the ReBentos Estuaries protocol with current international strategies with similar objectives.

\section{MATERIAL AND METHODS}

A review of all work published in peer-reviewed and indexed journals up to and including 2012 was made by means of the Web of Science ${ }^{\circledR}$, SCOPUS and Google Scholar. Benthic compartments, including meiofauna, macrofauna and megafauna, were selected after satisfying the basic criterion of focusing on community ecology. Taxonomic surveys and other specific work on benthic fauna were not included in this review but can be found elsewhere (LANA et al., 1996). Selected papers were classified according to 1) region (N, NE, SE and $\mathrm{S}$ ), 2) habitat (mangrove forest, saltmarsh, unvegetated sediments), 3) tidal position (subtidal or intertidal), and 4) sampling interval (months to years and number of sampling events during the study).

\section{RESULTS}

A total of 50 published papers on the benthic estuarine communities of 48 different estuaries were found (Table 1). These papers cover roughly three decades of study - from 1986 to 2012, with sampling efforts concentrated in the more developed areas of southern and southeastern Brazil (ca. 75\% of published papers; Figure 1). Despite the greater number of studies of estuaries from the southeastern and southern regions, most published works were concentrated on a few sites (Figure 1). The Northeastern region had a higher number of estuaries studied than did the Northern region, although both had generally a lower number of studies published (Figure 1). The sampling effort was greater in a few estuaries in the $\mathrm{S}$ and SE. For example, the estuarine systems of Guanabara Bay (RJ), Cananéia (SP), Paranaguá Bay (PR) and Patos Lagoon (RS) were intensely studied in respect to their benthic fauna and ecosystem dynamics (Table 1). On the other hand, most estuaries were investigated in respect to their community description on local to regional scales and only at a few sites were studies of a more general nature (e.g. community succession, pollution effects, trophic interactions) or where in situ experimentation been carried out included.

Benthic macrofaunal communities in subtidal channels and on intertidal flats were the most studied estuarine habitats along the Brazilian coast (Figure 1). Macrofaunal communities in saltmarshes (Spartina) were mainly studied on the northern and southern coasts in Pará, Santa Catarina, Paraná and Rio Grande do Sul (Figure 1). Megafaunal communities were mostly studied in mangrove forests and on hard substrates, with some efforts made in subtidal estuarine channels in some areas. On the eastern and southeastern coasts, macrofaunal and megafaunal communities were investigated in the polluted urban areas of the Pernambuco coast, Vitoria (ES), Guanabara (RJ) and Santos (SP). Benthic communities in mangrove forests and, saltmarshes and tidal flats were also studied in a few preserved areas of Rio de Janeiro and São Paulo in the southeast (Table 1). Significant sampling efforts on intertidal communities of unvegetated flats, saltmarshes and mangrove sediments were carried out in estuaries on the southern coast. In general, epifaunal communities in mangrove forests and Spartina marshes and on rocky substrates at specific sites were little studied.

Most benthic estuarine studies in Brazil have focused either on the description of patterns of community 
Table 1. Summary of selected published papers on the benthic ecology of Brazilian estuaries from 1986 to 2012.

\begin{tabular}{|c|c|c|c|c|c|c|c|}
\hline Area & State & $\begin{array}{c}\text { Estuarine } \\
\text { Habitats }\end{array}$ & Site & Depth & $\begin{array}{c}\text { Sampling } \\
\text { interval }\end{array}$ & $\begin{array}{c}\text { Benthic } \\
\text { fauna }\end{array}$ & Reference \\
\hline \multirow[t]{3}{*}{$\begin{array}{l}\text { Pará, Northern } \\
\text { Brazil }\end{array}$} & $\mathrm{PA}$ & Tidal flat & $\begin{array}{l}\text { Caeté } \\
\text { estuary }\end{array}$ & Intertidal & 2 days & Macrofauna & $\begin{array}{l}\text { ROSA FILHO et } \\
\text { al., } 2006\end{array}$ \\
\hline & PA & $\begin{array}{l}\text { Saltmarsh } \\
\text { (Spartina) }\end{array}$ & $\begin{array}{c}\text { Eight } \\
\text { estuaries } \\
\text { along Pará } \\
\text { coast }\end{array}$ & Intertidal & $\begin{array}{l}1 \text { year, } 4 \\
\text { sampling } \\
\text { events }\end{array}$ & Macrofauna & $\begin{array}{l}\text { BRAGA et al., } \\
2011\end{array}$ \\
\hline & $\mathrm{PA}$ & Mangrove & $\begin{array}{l}\text { Caeté } \\
\text { estuary }\end{array}$ & & $\begin{array}{c}1 \text { sampling } \\
\text { event }\end{array}$ & Megafauna & $\begin{array}{c}\text { KOCH and } \\
\text { WOLFF, } 2002\end{array}$ \\
\hline \multirow[t]{3}{*}{$\begin{array}{l}\text { Pernambuco, } \\
\text { Northeast Brazil }\end{array}$} & $\mathrm{PE}$ & Mangrove & $\begin{array}{l}\text { Itamaracá } \\
\text { Island }\end{array}$ & Intertidal & $\begin{array}{c}\text { Not } \\
\text { determined }\end{array}$ & Megafauna & $\begin{array}{l}\text { COELHO DOS } \\
\text { SANTOS and } \\
\text { COELHO, } 2001\end{array}$ \\
\hline & $\mathrm{PE}$ & Mangrove & Suape Bay & & $\begin{array}{c}1 \text { sampling } \\
\text { event }\end{array}$ & Megafauna & $\begin{array}{c}\text { FARRAPEIRA et } \\
\text { al., } 2009\end{array}$ \\
\hline & $\mathrm{PE}$ & Channel & $\begin{array}{l}\text { Fourteen } \\
\text { estuaries of } \\
\text { PE State }\end{array}$ & Subtidal & $\begin{array}{c}1 \text { sampling } \\
\text { event }\end{array}$ & Macrofauna & $\begin{array}{l}\text { VALENÇA and } \\
\text { SANTOS, } 2012\end{array}$ \\
\hline \multirow[t]{6}{*}{$\begin{array}{l}\text { Bahia, Northeast } \\
\text { Brazil }\end{array}$} & BA & $\begin{array}{c}\text { Mangrove } \\
\text { and Channel }\end{array}$ & $\begin{array}{l}\text { Cachoeira } \\
\text { river, Ilhéus }\end{array}$ & $\begin{array}{c}\text { Intertidal and } \\
\text { subtidal }\end{array}$ & $\begin{array}{l}5 \text { years - } \\
\text { qualitative } \\
\text { only }\end{array}$ & Megafauna & $\begin{array}{l}\text { ALMEIDA et al., } \\
2006\end{array}$ \\
\hline & $\mathrm{BA}$ & Channel & $\begin{array}{l}\text { Paraguaçu } \\
\text { river }\end{array}$ & & $\begin{array}{c}6 \text { months, } \\
2 \text { sampling } \\
\text { events }\end{array}$ & Macrofauna & $\begin{array}{l}\text { BARROS et al., } \\
2008\end{array}$ \\
\hline & $\mathrm{BA}$ & Channel & $\begin{array}{c}\text { Paraguaçu, } \\
\text { Subaé and } \\
\text { Jaguaripe } \\
\text { rivers }\end{array}$ & & $\begin{array}{c}6 \text { months, } \\
2 \text { sampling } \\
\text { events }\end{array}$ & Macrofauna & $\begin{array}{c}\text { MAGALHAES } \\
\text { and BARROS, } \\
2011\end{array}$ \\
\hline & BA & Channel & $\begin{array}{l}\text { Camamu } \\
\text { Bay }\end{array}$ & Subtidal & $\begin{array}{c}1 \text { sampling } \\
\text { event }\end{array}$ & Macrofauna & $\begin{array}{c}\text { PAIXÃO et al., } \\
2011\end{array}$ \\
\hline & BA & Channel & $\begin{array}{l}\text { Cachoeira } \\
\text { river, Ilhéus }\end{array}$ & Subtidal & $\begin{array}{l}1 \text { year, } \\
\text { monthly }\end{array}$ & Macrofauna & $\begin{array}{l}\text { OURIVES et al., } \\
2011\end{array}$ \\
\hline & BA & Channel & $\begin{array}{l}\text { Paraguaçu, } \\
\text { Subaé and } \\
\text { Jaguaripe } \\
\text { rivers }\end{array}$ & & $\begin{array}{c}6 \text { months, } \\
2 \text { sampling } \\
\text { events }\end{array}$ & Macrofauna & $\begin{array}{l}\text { BARROS et al., } \\
2012\end{array}$ \\
\hline \multirow[t]{2}{*}{$\begin{array}{l}\text { Espírito Santo, } \\
\text { Southeast Brazil }\end{array}$} & ES & Channel & Vitoria Bay & $\begin{array}{l}\text { Intertidal and } \\
\text { subtidal }\end{array}$ & $\begin{array}{l}1 \text { year, every } \\
3 \text { months }\end{array}$ & Macrofauna & $\begin{array}{l}\text { NALESSO et al., } \\
2005\end{array}$ \\
\hline & $\mathrm{ES}$ & Rocky & Vitória Bay & & $\begin{array}{l}3 \text { months, } \\
6 \text { sampling } \\
\text { events }\end{array}$ & $\begin{array}{l}\text { Megafauna } \\
\text { and } \\
\text { macrofauna }\end{array}$ & $\begin{array}{l}\text { ZALMON et al., } \\
2011\end{array}$ \\
\hline \multirow[t]{3}{*}{$\begin{array}{l}\text { Rio de Janeiro. } \\
\text { Southeast Brazil }\end{array}$} & RJ & Mangrove & $\begin{array}{l}\text { Sepetiba } \\
\text { Bay }\end{array}$ & Intertidal & $\begin{array}{l}1 \text { year, } 6 \\
\text { sampling } \\
\text { events }\end{array}$ & Megafauna & $\begin{array}{c}\text { OSHIRO et al., } \\
1998\end{array}$ \\
\hline & RJ & Channel & $\begin{array}{c}\text { Guanabara } \\
\text { Bay }\end{array}$ & Subtidal & $\begin{array}{l}3 \text { years, } 4 \\
\text { sampling } \\
\text { events }\end{array}$ & Megafauna & $\begin{array}{l}\text { LAVRADO et al., } \\
2000\end{array}$ \\
\hline & RJ & Channel & $\begin{array}{c}\text { Guanabara } \\
\text { Bay }\end{array}$ & Subtidal & $\begin{array}{l}1 \text { year, } 2 \\
\text { sampling } \\
\text { events }\end{array}$ & Macrofauna & $\begin{array}{c}\text { SOARES-GOMES } \\
\text { et al., } 2012\end{array}$ \\
\hline
\end{tabular}


São Paulo,

Southeast Brazil

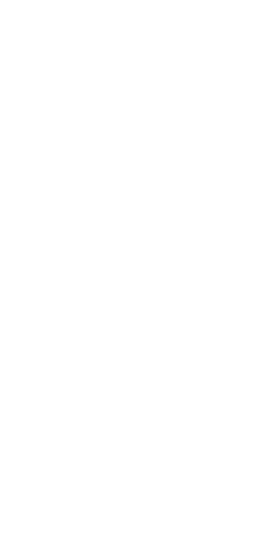

Paraná, South

Brazil

\begin{tabular}{|c|c|c|c|c|c|c|c|}
\hline & RJ & Channel & $\begin{array}{c}\text { Guanabara } \\
\text { Bay }\end{array}$ & Subtidal & $\begin{array}{l}1 \text { year, } 2 \\
\text { sampling } \\
\text { events }\end{array}$ & Macrofauna & $\begin{array}{c}\text { SANTI and } \\
\text { TAVARES, } 2009\end{array}$ \\
\hline & RJ & Tidal flats & $\begin{array}{c}\text { Guanabara } \\
\text { Bay }\end{array}$ & Intertidal & $\begin{array}{l}1 \text { year, } 3 \text { sam- } \\
\text { pling events }\end{array}$ & Macrofauna & $\begin{array}{l}\text { OMENA et al., } \\
2012\end{array}$ \\
\hline & RJ & Rocky & $\begin{array}{c}\text { Guanabara } \\
\text { Bay }\end{array}$ & Intertidal & $\begin{array}{c}2 \text { years, } 8 \\
\text { sampling } \\
\text { events }\end{array}$ & Megafauna & $\begin{array}{l}\text { JUNQUEIRA et } \\
\text { al., } 2000\end{array}$ \\
\hline & RJ & Channel & $\begin{array}{l}\text { Saquarema- } \\
\text {-Jaconé }\end{array}$ & Subtidal & $\begin{array}{l}1 \text { year, } 4 \\
\text { sampling } \\
\text { events }\end{array}$ & Macrofauna & $\begin{array}{l}\text { MENDES and } \\
\text { SOARES- } \\
\text { GOMES, } 2011\end{array}$ \\
\hline \multirow[t]{6}{*}{$\begin{array}{l}\text { São Paulo, } \\
\text { Southeast Brazil }\end{array}$} & SP & Mangrove & $\begin{array}{c}\text { Seven } \\
\text { mangrove } \\
\text { areas in the } \\
\text { state }\end{array}$ & Intertidal & $\begin{array}{l}1 \text { year, } \\
\text { monthly }\end{array}$ & Megafauna & $\begin{array}{l}\text { COLPO et al., } \\
2011\end{array}$ \\
\hline & SP & Saltmarsh & $\begin{array}{l}\text { Cananéia } \\
\text { estuary }\end{array}$ & Intertidal & $\begin{array}{l}1 \text { year, mon- } \\
\text { thly }\end{array}$ & Macrofauna & $\begin{array}{c}\text { TARARAM and } \\
\text { WAKABARA, } \\
1987\end{array}$ \\
\hline & SP & Channel & $\begin{array}{l}\text { Cananéia } \\
\text { estuary }\end{array}$ & Subtidal & $\begin{array}{c}1 \text { sampling } \\
\text { event }\end{array}$ & Macrofauna & TOMMASI, 1970 \\
\hline & SP & Tidal flats & $\begin{array}{l}\text { Cananéia } \\
\text { estuary }\end{array}$ & Intertidal & $\begin{array}{l}1 \text { year, } 5 \\
\text { sampling } \\
\text { events }\end{array}$ & Macrofauna & VAROLI, 1990 \\
\hline & SP & Tidal flats & $\begin{array}{l}\text { Santos } \\
\text { estuarine } \\
\text { system }\end{array}$ & Intertidal & $\begin{array}{l}1 \text { year, } 4 \\
\text { sampling } \\
\text { events }\end{array}$ & Macrofauna & CORBISIER, 1991 \\
\hline & SP & Saltmarsh & $\begin{array}{l}\text { Cananéia } \\
\text { estuary }\end{array}$ & Intertidal & $\begin{array}{l}1 \text { year, } 8 \\
\text { sampling } \\
\text { events }\end{array}$ & Macrofauna & $\begin{array}{c}\text { ATTOLINI et al., } \\
1997\end{array}$ \\
\hline \multirow[t]{9}{*}{$\begin{array}{l}\text { Paraná, South } \\
\text { Brazil }\end{array}$} & PR & Tidal flats & $\begin{array}{c}\text { Guaratuba } \\
\text { Bay }\end{array}$ & Intertidal & $\begin{array}{l}1 \text { year, } \\
\text { monthly }\end{array}$ & Megafauna & MASUNARI, 2006 \\
\hline & PR & Channel & $\begin{array}{c}\text { Paranaguá } \\
\text { Bay }\end{array}$ & Subtidal & $\begin{array}{c}1 \text { sampling } \\
\text { event }\end{array}$ & Macrofauna & LANA, 1986 \\
\hline & PR & $\begin{array}{l}\text { Saltmarsh } \\
\text { (Spartina } \\
\text { alterniflora) }\end{array}$ & $\begin{array}{l}\text { Paranaguá } \\
\text { Bay }\end{array}$ & Intertidal & $\begin{array}{l}14 \text { months, } \\
\text { monthly } \\
\text { sampling }\end{array}$ & Macrofauna & $\begin{array}{c}\text { LANA and GUISS, } \\
1991\end{array}$ \\
\hline & PR & Tidal flats & $\begin{array}{l}\text { Paranaguá } \\
\text { Bay }\end{array}$ & Intertidal & $\begin{array}{l}\text { up to } 18 \text { days } \\
\text { (experimental) }\end{array}$ & Macrofauna & $\begin{array}{l}\text { NETTO and } \\
\text { LANA, } 1994\end{array}$ \\
\hline & PR & Tidal flats & $\begin{array}{l}\text { Paranaguá } \\
\text { Bay }\end{array}$ & Intertidal & $\begin{array}{l}6 \text { months, } \\
2 \text { sampling } \\
\text { events }\end{array}$ & Macrofauna & $\begin{array}{l}\text { NETTO and } \\
\text { LANA, } 1997\end{array}$ \\
\hline & PR & $\begin{array}{c}\text { Tidal } \\
\text { flats, Salt } \\
\text { marshes and } \\
\text { Mangrove }\end{array}$ & $\begin{array}{l}\text { Paranaguá } \\
\text { Bay }\end{array}$ & Intertidal & $\begin{array}{l}1 \text { sampling } \\
\text { event }\end{array}$ & Macrofauna & LANA et al., 1997 \\
\hline & PR & $\begin{array}{l}\text { Spartina salt } \\
\text { marsh }\end{array}$ & $\begin{array}{c}\text { Paranaguá } \\
\text { Bay }\end{array}$ & Intertidal & $\begin{array}{l}6 \text { months, } \\
2 \text { sampling } \\
\text { events }\end{array}$ & Macrofauna & $\begin{array}{l}\text { NETTO and } \\
\text { LANA, } 1999\end{array}$ \\
\hline & PR & $\begin{array}{l}\text { Tidal flats } \\
\text { and Channel }\end{array}$ & $\begin{array}{l}\text { Baía de } \\
\text { Guaratuba }\end{array}$ & Subtidal & $\begin{array}{c}1 \text { sampling } \\
\text { event }\end{array}$ & Macrofauna & $\begin{array}{l}\text { BLANKENSTEYN } \\
\text { and MOURA, } 2002\end{array}$ \\
\hline & PR & Tidal flats & $\begin{array}{c}\text { Paranaguá } \\
\text { Bay }\end{array}$ & Intertidal & $\begin{array}{c}64 \text { days } \\
\text { (exeprimental) }\end{array}$ & Macrofauna & $\begin{array}{l}\text { FARACO and } \\
\text { LANA, } 2003\end{array}$ \\
\hline
\end{tabular}


Continued Table 1.

\begin{tabular}{|c|c|c|c|c|c|c|c|}
\hline & PR & Tidal flats & $\begin{array}{c}\text { Paranaguá } \\
\text { Bay }\end{array}$ & Intertidal & $\begin{array}{c}95 \text { days } \\
\text { (experimental) }\end{array}$ & Macrofauna & $\begin{array}{l}\text { FARACO and } \\
\text { LANA, } 2004\end{array}$ \\
\hline & PR & Salt marshes & $\begin{array}{c}\text { Paranaguá } \\
\text { Bay }\end{array}$ & Intertidal & $\begin{array}{c}120 \text { days } \\
\text { (experimental) }\end{array}$ & Macrofauna & $\begin{array}{l}\text { PAGLIOSA and } \\
\text { LANA, } 2005\end{array}$ \\
\hline \multirow[t]{5}{*}{$\begin{array}{l}\text { Santa Catatrina, } \\
\text { South Brazil }\end{array}$} & $\mathrm{SC}$ & Mangrove & $\begin{array}{c}\text { Estuary of } \\
\text { Ratones } \\
\text { River }\end{array}$ & Intertidal & $\begin{array}{c}1 \text { sampling } \\
\text { event }\end{array}$ & $\begin{array}{c}\text { Meiofauna } \\
\text { and } \\
\text { Macrofauna }\end{array}$ & $\begin{array}{c}\text { NETTO and } \\
\text { GALLUCCI, } 2003\end{array}$ \\
\hline & $\mathrm{SC}$ & Channel & $\begin{array}{l}\text { Laguna } \\
\text { Estuarine } \\
\text { System }\end{array}$ & Subtidal & $\begin{array}{c}2 \text { sampling } \\
\text { events }\end{array}$ & Macrofauna & $\begin{array}{l}\text { FONSECA and } \\
\text { NETTO, } 2006\end{array}$ \\
\hline & $\mathrm{SC}$ & $\begin{array}{c}\text { Mangrove } \\
\text { and Channel }\end{array}$ & $\begin{array}{l}\text { Bay of } \\
\text { Santa } \\
\text { Catarina } \\
\text { island }\end{array}$ & Subtidal & $\begin{array}{c}1 \text { sampling } \\
\text { event }\end{array}$ & Macrofauna & $\begin{array}{l}\text { PAGLIOSA and } \\
\text { BARBOSA, } 2006\end{array}$ \\
\hline & $\mathrm{SC}$ & Channel & $\begin{array}{l}\text { Laguna } \\
\text { Estuarine } \\
\text { System }\end{array}$ & Subtidal & $\begin{array}{c}1 \text { year, } 12 \\
\text { sampling } \\
\text { events }\end{array}$ & Macrofauna & $\begin{array}{l}\text { MEURER and } \\
\text { NETTO, } 2007\end{array}$ \\
\hline & $\mathrm{SC}$ & Mangrove & $\begin{array}{c}\text { Santa } \\
\text { Catarina } \\
\text { island }\end{array}$ & Intertidal & $\begin{array}{c}1 \text { year, } 13 \\
\text { sampling } \\
\text { events }\end{array}$ & Megafauna & BRANCO, 1990 \\
\hline \multirow[t]{6}{*}{$\begin{array}{l}\text { Rio Grande do } \\
\text { Sul, South Brazil }\end{array}$} & RS & Tidal flats & $\begin{array}{l}\text { Patos } \\
\text { Lagoon }\end{array}$ & Intertidal & $\begin{array}{l}1 \text { sampling } \\
\text { event }\end{array}$ & Macrofauna & $\begin{array}{c}\text { ROSA and } \\
\text { BEMVENUTI, } \\
2004\end{array}$ \\
\hline & RS & Tidal flats & $\begin{array}{l}\text { Patos } \\
\text { Lagoon }\end{array}$ & Intertidal & $\begin{array}{l}6 \text { months, } \\
4 \text { sampling } \\
\text { events }\end{array}$ & Macrofauna & $\begin{array}{l}\text { BEMVENUTI et } \\
\text { al., } 2003\end{array}$ \\
\hline & RS & Channel & $\begin{array}{l}\text { Patos } \\
\text { Lagoon }\end{array}$ & Subtidal & $\begin{array}{c}63 \text { days } \\
\text { (experimental) }\end{array}$ & Macrofauna & $\begin{array}{c}\text { SOARES et al., } \\
2004\end{array}$ \\
\hline & RS & Channel & $\begin{array}{l}\text { Patos } \\
\text { Lagoon }\end{array}$ & Subtidal & $\begin{array}{c}1 \text { year, } 4 \\
\text { sampling } \\
\text { events }\end{array}$ & Macrofauna & $\begin{array}{l}\text { BEMVENUTI et } \\
\text { al., } 2005\end{array}$ \\
\hline & RS & Tidal flats & $\begin{array}{c}\text { Patos } \\
\text { Lagoon }\end{array}$ & Intertidal & $\begin{array}{c}1 \text { year, } 12 \\
\text { sampling } \\
\text { events }\end{array}$ & Macrofauna & $\begin{array}{l}\text { COLLING et al., } \\
2007\end{array}$ \\
\hline & $\mathrm{RS}$ & $\begin{array}{l}\text { Saltmarsh } \\
\text { (Ruppia } \\
\text { maritima) }\end{array}$ & $\begin{array}{l}\text { Patos } \\
\text { Lagoon }\end{array}$ & Subtidal & $\begin{array}{l}2 \text { sampling } \\
\text { events }\end{array}$ & Macrofauna & $\begin{array}{l}\text { ROSA and BE- } \\
\text { MVENUTI, } 2007\end{array}$ \\
\hline
\end{tabular}
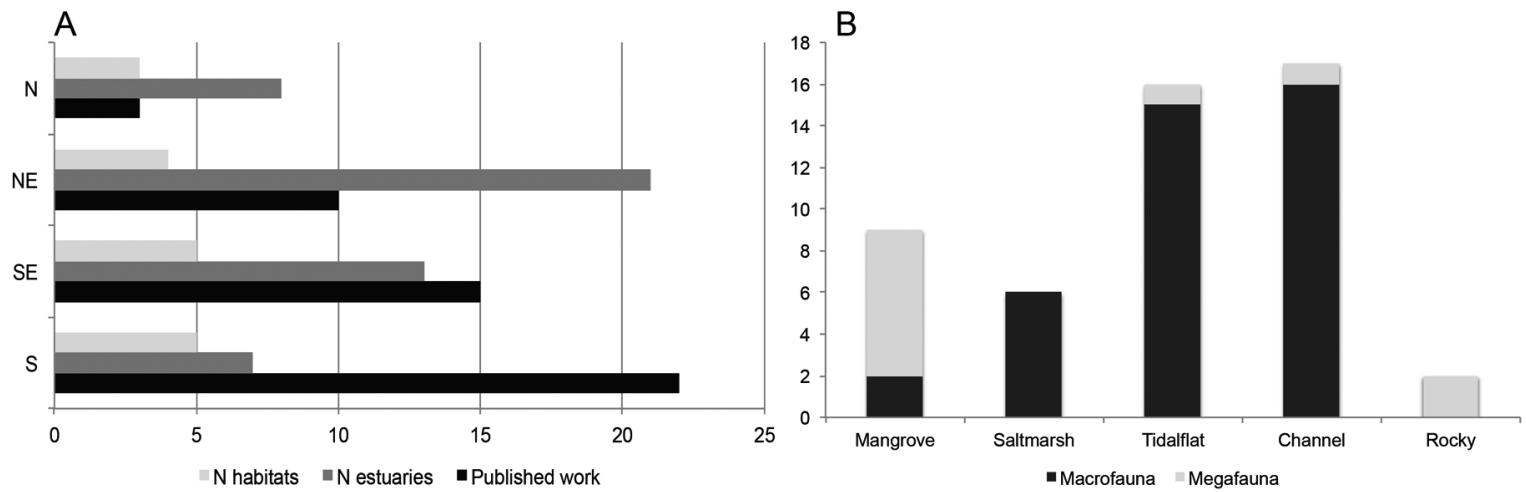

Figure 1. A. Distribution of selected published studies on benthic estuarine communities, number of estuaries and habitats within each region along the Brazilian coast from 1986 to 2012. B. Number of studies per habitat and proportion of studies addressing macrofaunal or megafaunal communities. 
distribution and structure, or their relationship with environmental drivers and pollution effects. Descriptive studies overwhelmingly dominate those of all estuarine habitats and account for $60 \%$ of all published papers. Changes in community structure occur due to spatial changes of salinity, sediment composition and hydrodynamics at both tropical and subtropical estuaries (LANA et al., 1997; FONSECA and NETTO, 2006; COLLING et al., 2007; BARROS et al., 2008). The influence of habitat on benthic communities is also closely related to the vegetation and its organic detritus in addition to changes in the structure and distribution of communities between rainy and dry seasons (NETTO and LANA, 1999; PAGLIOSA and LANA, 2000; COLLING et al., 2007; MEURER and NETTO, 2007). Overall, there is a local increase in benthic species richness at vegetated sediments, most likely due the increased habitat complexity (NETTO and LANA, 1999).

The spatial and temporal patterns of benthic communities were investigated through a few $(n=1$ to 4) sampling events during 6-month periods. The abiotic factors investigated included salinity, sediment properties (i.e. grain size and organic matter), presence or absence of vegetation and natural or anthropogenic disturbance (i.e. physical disturbance of sediment and pollution. Table 1). Seasonal dynamics of benthic fauna, over up to a year, were less often investigated (38\% of published papers). Unvegetated flats and channels were commonly studied through monthly sampling (sometimes less frequently) for periods of a year. The benthic fauna of vegetated mangrove forests and salt marsh sediments were rarely sampled for periods longer than 6 months (Table 1). Long-term studies, which includes those on inter-annual temporal scales of $>2$ years, are clearly missing for all benthic estuarine habitats except for a few exceptions across Brazil $(n=4)$. Information on seasonal and interannual variability of benthic estuarine communities is spatially highly limited. For example, we have found a 4-year qualitative survey on the carcinofauna of mangrove forests and estuarine sediments in NE Brazil (ALMEIDA et al., 2006). Another 3-year sampling with only 4 trawling campaigns studied the benthic megafauna within Guanabara Bay, which was also studied in respect to its rocky shore communities over a 2-year period (JUNQUEIRA et al., 2000; LAVRADO et al., 2000). The longest time series study of benthic macrofauna was carried out on a saltmarsh in Paranaguá Bay (LANA and GUISS, 1991), which was sampled monthly for 14 months.

\section{DISCUSSION}

\section{MOVING FROM COMMUNITY STRUCTURE TO}

\section{ECOLOGICAL PROCESSES}

There is an urgent need to increase the number of field surveys in poorly studied regions. Past and current descriptive efforts are clearly important to describe and discriminate varying estuarine patterns along the Brazilian coast. As these estuaries are fundamentally distinct in respect to their geomorphology and oceanographic conditions and are under various climatic regimes, additional investigations will certainly lead to a better recognition of associated benthic communities and sitespecific responses (GILLANDERS and KINGSFORD, 2002; SOARES et al., 2014). Indeed, there is strong evidence for local and regional heterogeneity of estuarine benthic communities among habitats (NETTO and LANA, 1997; EDGAR and BARRETT, 2002; BARROS et al., 2012). Such heterogeneity may lead to variable community-environment responses of benthic fauna at different estuaries. In any case, these surveys would clearly benefit from standard protocols for community assessment and data analysis, allowing the identification of large scale patterns and potentially leading to more accurate models.

However, it is also necessary to move research questions from the basic descriptions of community structure to the understanding of the ecological processes that regulate benthic dynamics in Brazilian estuaries. The investigation of ecological processes in benthic communities has advanced through intensive sampling and field manipulative experiments in SE and S Brazil, with greater effort directed to unvegetated flats and saltmarshes. As has been revealed for temperate and tropical estuaries in the Northern hemisphere, significant differences in community structure, succession and trophic processes occur between vegetated and unvegetated sediments in subtropical estuaries (LANA and GUISS, 1992; NETTO and LANA, 1999). Manipulative and mensurative experiments also revealed the responses of benthic communities to nutrient loading and pollution effects, which greatly improved our understanding of mechanisms of community resilience and succession after disturbance (FARACO and LANA, 2003; MENDES and SOARES-GOMES, 2011; GERN and LANA, 2013; SOUZA et al., 2013). Recognising these patterns on local and regional scales allows for better predictive models of benthic community responses to habitat modification, species invasion and subsequent changes in sediment 
biogeochemistry (NEIRA et al., 2005; DEMOPOULOS et al., 2007; CANNICCI et al., 2008; DEMOPOULOS and SMITH, 2010; SWEETMAN et al., 2010). In order to build strong models to detect wide ecosystem impacts from climate change (SCAVIA et al., 2002; KOTTA et al., 2009; SEMENIUK, 2013), we will need replicated experiments on a large latitudinal scale at several Brazilian estuaries.

Broad changes in the structure and functioning of benthic estuarine communities are expected with the projected changes in sea level, temperature and rainfall (NAJJAR et al., 2000; GILLANDERS and KINGSFORD, 2002; MILLIMAN et al., 2008; NICHOLLS and CAZENAVE, 2010; DONEY et al., 2012; BERNARDINO et al., 2015a). Significant changes in rainfall extremes and dry cells have been projected for South America (MARENGO et al., 2010). They include an increase in extreme precipitation events over most of Southeastern South America and Western Amazonia consistent with projected increasing trends in total rainfall. Smaller or no changes in rainfall intensity have been foreseen for Northeast Brazil and Eastern Amazonia, though significant changes are expected in the frequency of consecutive dry days. On estuary- scale, benthic species distribution, diversity and dynamics across salinity gradients may change significantly (ELLIOTT and WHITFIELD, 2011; WHITFIELD et al., 2012). As salinitycommunity patterns for Brazilian estuaries are understudied in most regions, the loss of species or community changes in these areas will lead to uncertainties about changes in key ecological processes. The benthic fauna associated with vegetated habitats will also be heavily impacted due to habitat loss, which will impact production and trophic processes (LEE, 1998). Sea-level rise effects on Brazilian estuaries are largely uncertain, but will likely lead to loss of mangrove and saltmarsh ecosystems and their services, including carbon sequestration (DUARTE et al., 2005; DONATO et al., 2011). It is clear that most estuarine areas within urban regions will be severely impacted or disappear as vegetated ecosystems will fail to migrate onshore due to coastal development (SHORT and NECKLES, 1999; ALONGI, 2008).

In summary, few ecological and biogeochemical processes mediated by benthic organisms in Brazilian estuaries have been investigated, which precludes reasonable mitigation and conservation strategies if projected changes are confirmed. Mechanisms of benthic production and functional effects on communities in response to natural and anthropogenic disturbance need to be investigated on a multi-scale perspective. It is clear that current and future investigations of estuarine processes need to include the role of benthic communities in sediment biogeochemistry, to address the ecological effects of changes in environment and habitat, and finally to make quantitative predictions of potential environmental, economical and societal changes.

\section{INCREASE LONG-TERM SCIENTIFIC AND MONITORING}

\section{EFFORTS}

The question of scale in ecology has received much recent attention (LEVIN, 1992; SCHNEIDER, 2001). Studying large temporal scales of ecological processes has been a major challenge for ecologists as well as securing funds for the long-term approaches that are needed to understand these processes. In this context, studies of pattern have become still been more frequent in science, but are strikingly few regarding estuarine ecosystems in Brazil. A number of the ecological benefits provided by estuaries have been independently investigated at a number of sites in Brazil over recent decades (RONDINELLI and BARROS, 2010; PENDLETON et al., 2012; VILAR et al., 2013), but we have no systematic efforts, dedicated funding programs or networks to study Brazilian estuaries. Additionally, the short-term scale (i.e. less than 1-yr) of most studies means that we do not have scientific data on relevant temporal scales to characterize, manage or protect most estuaries and their associated communities in Brazil.

As estuaries are naturally dynamic ecosystems and associated with coastal and riverine hydromorphology, we need to understand changes in their communities and ecological processes on decadal scales in the light of meaningful temporal scales of riverine, marine and climate forces (SCAVIA et al., 2002; ELLIOTT and WHITFIELD, 2011). Long-term studies, with duration of $>2 \mathrm{yrs}$, have an increased power to detect communitywide responses to intra-annual and inter-annual changes in estuarine dynamics. A number of community processes driven by benthic organisms suffer significant changes on time scales longer than a year. For example, population dynamics and benthic annual production rates may vary significantly on annual and decadal scales due to changes in estuarine productivity, temperature, disturbance regimes, catastrophic events and interacting factors (KOTTA et al., 2009; DOLBETH et al., 2011). Although functional indices such as productivity regimes offer advantages in depicting ecosystem-wide responses, large variability in productivity may occur between estuaries due to site-specific differences such as pelagic productivity (CONDIE et al., 2012). Therefore, the multiple mechanisms that lead to changes in 
production and population dynamics over long-term periods suggest that estuarine ecosystems must be investigated on multiple scales.

The ReBentos Estuaries working group has proposed a study protocol for benthic estuarine communities that meets the above criteria of i) standardisation of methods; ii) working with functional and biodiversity indices, and iii) multiple scales. The protocol has been designed to address projected and observed changes in mean atmospheric temperatures and in yearly rainfall at estuaries in the major climatic regions of Brazil (MARENGO et al., 2010; BERNARDINO et al., 2015b). With scientific hypotheses based on projected changes, we suggested a standard protocol for studying temporal patterns in productivity and diversity of megafaunal and macrofaunal benthic communities. The working group has so far started field work on a total of eight estuaries located in the major regions of Brazil. These estuaries were selected based on their accessibity to various research groups and on existing protected areas (i.e. federal, state or municipal). At each estuary, the working group has started quarterly acquisition of biological and environmental data, with replicated campaigns after dry and wet seasons. We believe that these assessments must be continued, not only to reveal large scale spatial and temporal patterns of benthic estuarine communities, but also to test the hypothesis with long-term data. However, although the ReBentos working group has received a limited startup funding of 3 years, continuous assessments at these estuaries from Northern to Southern Brazil may have to be interrupted.

\section{WHAT INTERNATIONAL PROGRAMS CAN TEACH US}

The International Long-term Ecological Research Network (ILTER) is an example of a global network of scientists engaged in long-term, site based ecological and socioeconomic research, with the mission of understanding global ecosystems and providing potential solutions to current and future global problems, considering the human dimensions of environmental change. The goals of ILTER are to coordinate long-term ecological research in integrated and collaborative networks; to improve comparability of long-term ecological data through simple field and lab protocols; to generate and transmit better scientific information to scientists, policymakers and the public; and to facilitate education of the next generation of longterm scientists. The PELD program (Long-term Ecological Researches), created by the Brazilian National Research Council (CNPq) - Ministry of Science, Technology and
Innovation in 1998, was clearly influenced by ILTER. The PELD program is promoting and funding a series of fruitful projects, but none of them have addressed estuarine benthic dynamics on a national scale (TABARELLI et al., 2013).

The U.S. National Environmental Protection Agency has started an Estuary Program (NEP) that initiated several networks with broad objectives including protection and resource governance (SCHNEIDER et al., 2003). Providing up to 5-year funding for creation of management plans for 28 estuaries across the U.S., the NEP program has fostered networks with regional representatives of government, business, citizens, educators and researchers. These networks have been successfully bridging scientific knowledge with policy discussions, and have resulted in the better assessment of impacts on estuaries and their watersheds (SCHNEIDER et al., 2003; MERRIFIELD et al., 2011). Although NEP programs often target regional human impacts on estuaries, the identification of commonalities or dissimilarities in estuarine ecosystems significantly ensures better climate change response and management in these areas (MERRIFIELD et al., 2011). Cimate preparedness and response for estuaries also comes from the US EPA agency specific program named Climate Ready Estuaries (http://water.epa.gov/type/oceb/cre/index. $\mathrm{cfm})$. This program assists the NEP program directly through network actions, and both programs benefit from information produced on scales from local to regional. These joint network efforts are excellent innitiatives for the better practice of estuarine management.

In the European Union, environmental threats to coastal areas have led to political action to protect estuarine and other ecosystems from the effects of human activities (FERREIRA et al., 2011). These policies ultimately led to a Water Strategy Framework Directive (WFD) designed to investigate ecosystem function and to establish guidelines for assessing environmental quality and long-term monitoring of coasts, estuaries and their watersheds (PARLIAMENT, 2000). The WFD has resulted in a number of studies that have developed guidelines to assess all aspects of water and ecosystem quality. As every EU country has been required to follow those directives, national scientific networks across the EU have applied integrated studies regionally to evaluate the ecosystem health of estuaries and their watersheds. In the estuaries and on the coasts of Europe, specific tools for the assessment of ecological status using benthic communities have been created (BORJA et al., 2000) and these have been independently tested in Brazil (MUNIZ et al., 2005; VALENÇA and SANTOS, 2012). 
Many other international initiatives across Europe have tested and developed guidelines to investigate benthic estuarine habitats in the long-term with management purposes (QUINTINO et al., 2006; RODRIGUES et al., 2011). As a result, a regulatory directive from the EU Parliament encouraged the creation of scientific and political networks with a view to the assessment of regional ecosystems, the testing of scientific methods and protocols, and coastal management.

These integrated efforts undoubtedly demonstrate that successful programs to protect estuaries call for sound science allied to political and societal engagement. The ReBentos network has started a unique and fruitful network - mainly composed of scientists - that could arouse interest in estuarine management and protection. However, Brazilian efforts to protect estuaries, and most coastal ecosystems, will be largely ineffective if only scientists pursue these objectives (SUNDERLAND et al., 2009). Successful programs to protect Brazilian estuaries from human and climate change impacts will need to be funded by public and private agencies (municipal, state and federal), with the involvement of all stakeholders including scientists, interested parties (e.g. traditional fishermen and industry), private and non-governmental organizations; and result in specific products for management of estuarine ecosystems. Funding for these programs needs to be priorized by federal and state environmental agencies (e.g. CNPq, CAPES, IBAMA; the Ministry of the Environment, the Ministry of Science) which are clearly key players responsible for ecosystem use and conservation. These programs must result in sound scientific practices, with well organized and public data bases (i.e. also funded and maintained by those sources). These programs should be further accompanied and evaluated by progress reports and subjected to rigorous national and international panel evaluations.

\section{ProspeCts OF THE STUDIES OF THE ESTUARIES SELECTED BY THE REBENTOS NETWORK}

Estuarine benthic communities have been extensively studied across the world and these studies include longterm network initiatives for monitoring. The overall result of changes in species richness, density and biomass related to salinity (MORTIMER et al., 1999; JOSEFSON \& HANSEN, 2004), sediment composition (MORRISEY et al., 2003), nutrient input (EDGAR \&
BARRETT 2002), geomorphology (HIRST, 2004) and oxygen availability (ROSENBERG, 1977; NILSSON \& ROSENBERG, 1997) is generally the same. Changes in these abiotic parameters are also related to river and ocean dynamics, natural seasonal climatic changes or anthropogenic impacts, influencing benthic communities (MONTAGNA \& KALKE, 1992; FUJII, 2007). Nevertheless, South American estuaries are frequently not included in the search for general ecological models (BARROS et al., 2012), and understanding the patterns and processes which occur along the Brazilian coast would constitute an important contribution to global discussion, due to the extent and diversity of the Brazilian coastline.

The macroscale investigation started by the ReBentos network was the first step towards an integrated approach which takes into account the variety of Brazilian estuaries, their benthic biodiversity and the assessment of the effects of projected climatic change on the goods and services they provide. The effects of large-scale factors on populations and communities are usually underpinned by hierarchical (top-down scale mediated processes) or multiscale (interactions among scales mediated processes) perspectives (HEWITT and THRUSH, 2007; 2009). Both perspectives must take spatial and temporal variation into account. Moving forward, registering, understanding, and reviewing climate change effects on estuarine benthos will require continuous and long-term monitoring. The systematic application of established monitoring protocols will highlight the large-scale and long-term relative importance of environmental factors in influencing spatial and temporal dynamics of benthic richness and abundance, and how their loss can affect estuarine resources and services. The integrated management across spatial and temporal scales and frequent monitoring of estuarine patterns and processes are essential tools for coastal management, since regions under higher pressure from human activities are more suceptible to climatic change impacts. Based on knowledge of the patterns and processes involved in estuarine systems on the long term, further conservation and management decisions can be taken to mitigate impacts. Thus our ability to make better predictions and to provide resource management agencies and policymakers with the best scientific information will depend largely on an increased effort aimed at using integrated research networks over long-term scales. 


\section{ACKNOWLEDGEMENTS}

Special thanks to Dr. Alexander Turra and Dr. Márcia Denadai and all the members of the ReBentos network for their support and for the many discussions whose results are presented here. Thanks to Dr. Stuart Jenkins for his revision of the English text. This study was funded by grants made by CNPq SISBIOTA and FAPESP to Alexander Turra. AFB is supported by grants from FAPES, nos. 52638090/2011 and CNPq 301412/2013-8. PM acknowledges the support received from SNI- ANII of Uruguay.

\section{REFERENCES}

ALMEIDA, A. O.; COELHO, P. A.; SANTOS, J. T. A.; FERRAZ, N. R. Crustáceos decápodos estuarinos de Ilhéus, Bahia, Brasil. Biota Neotrop., v. 6, n. 2, p. 1-24, 2006.

ALONGI, D. M. Mangrove forests: resilience, protection from tsunamis, and responses to global climate change. Estuar. Coast. Shelf Sci., v. 76, n.1, p. 1-13, 2008.

ANTLE, J.; APPS, M.; BEAMISH, R.; CHAPIN, T.; CRAMER, W.; FRANGI, J.; LAINE, J.; ERDA, L. Ecosystems and their goods and services. In: MCCARTHY, J. J.; CANZIANI, O. F., LEARY, N.A., DOKKEN D.J., WHITE K.S. (Eds.). Climate Change 2001: Impacts, Adaptation and Vulnerability. Cambridge: Cambridge University Press, 2001. p.235-342.

ATTOLINI, F. S.; FLYNN, M. N.; TARARAM, A. S. Influence of Spartina alterniflora and tide level on the structure of polychaete associations in an euryhaline salt marsh in Cananéia lagoon estuarine region (SE Brazil). Rev. Bras. Oceanogr., v. 45, n. 1/2, p. 25-34, 1997.

ATTRILL, M. J.; POWER, M. Effects on invertebrate populations of drought-induced changes in estuarine water quality. Mar. Ecol. Progr. Ser., v. 203, p. 133-143, 2000.

BARros, F.; CARVAlHO, G. C.; COSTA, Y.; HATJE, V. Subtidal benthic macroinfaunal assemblages in tropical estuaries: generality amongst highly variable gradients. Mar. Environ. Res., v. 81, p. 43-52, 2012.

BARROS, F.; HATJE, V.; FIGUEIREDO, M. B.; MAGALHÃES, W. F.; DÓREA, H. S.; EMÍDIO, E. S. The structurre of the benthic macrofaunal assemblages and sediments characteristics of the Paraguaçu estuarine system, NE, Brazil. Estuar. Coast. Shelf Sci., v. 78, n. 4, p. 753-762, 2008.

BEMVENUTI, C. E.; ANGONESI, L. G.; GANDRA, M. S. Effects of dredging operations on soft bottom macrofauna in a harbor in the Patos Lagoon estuarine region of southern Brazil. Braz. J. Biol., v. 65, n. 4, p. 573-581, 2005.

BEMVENUTI, C. E.; ROSA FILHO, J. S.; ELLIOTT, M. Changes in soft-bottom macrobenthic assemblages after a sulphuric acid spill in the Rio Grande Harbor (RS, Brazil). Braz. J. Biol., v. 63, n. 2, p. 183-194, 2003.

BERNARDINO, A.F., NETTO, S.A., PAGLIOSA, P.R., BARROS, F., CHRISTOFOLETTI, R.A., ROSA FILHO, J.S., COLling, A., LANA, P.C. Predicting ecological changes on benthic estuarine assemblages through decadal climate trends along Brazilian Marine Ecoregions. Estuar. Coast. Shelf Sci. v.166, p 74-82, 2015a.
BERNARDINO, A.F., BARROS, F., PEREZ, L.F., NETTO, S.A., COLLING, L.A., PAGLiOSA, P.R., LANA, P.C., MAIA, R.C., CHRISTOFOLETTI, R.A., ROSA FILHO, J.S., COSTA, T.M. Monitoramento de ecossistemas bentônicos estuarinos. In: Protocolos para o monitoramento de ecossistemas bentônicos costeiros - Rede de monitoramento de habitats bentônicos costeiros - Rebentos. Turra, A. \& Denadai, M.R. orgs. Comarte jr. Instituto Oceanográfico, São Paulo, Cap. 11, pp 134-154, 2015 b.

BISHOP, M. J.; POWERS, S. P.; PORTER, H. J.; PETERSON, C. H. Benthic biological effects of seasonal hypoxia in a eutrophic estuary predate rapid coastal development. Estuar. Coast. Shelf Sci., v. 70, n. 3, p. 415-422, 2006.

BLANKENSTEYN, A.; MOURA, R. S. Lista preliminar das espécies da macrofauna de fundos inconsolidados da Baía de Guaratuba, Paraná, Brasil. Rev. Bras. Zool., v. 19, n. 3, p. 715-721, 2002.

BORJA, A.; FRANCO, J.; PEREZ, V. A marine biotic index to establish the ecological quality of soft-bottom benthos within European estuarine and coastal environments. Mar. Pollut. Bull., v. 12, n. 4, p. 1100-1114, 2000.

BOTTER-CARVALHO, M. L.; CARVALHO, P. V. V. C.; SANTOS, P. J. P. Recovery of macrobenthos in defaunated tropical estuarine sediments. Mar. Pollut. Bull., v. 62, n. 8, p. 1867-1876, 2011.

BRAGA, C. F.; MONTEIRO, V. F.; ROSA FILHO, J. S.; BEASLEY, C. R. Benthic macrofaunal assemblages associated with Amazonian saltmarshes. Wetlands Ecol. Manage., v. 19, n. 3, p. 257-272, 2011.

BRANCO, J. O. Aspectos ecológicos dos Brachyura (Crustacea: Decapoda) no manguezal do Itacorubi, SC - Brasil. Rev. Bras. Zool., v. 7, n. 1/2, p. 165-179, 1990.

CANNICCI, S.; BURROWS, D.; FRATINI, S.; SMITH III, T. J.; OFFENBERG, J.; DAHDOUH-GUEBAS, F. Faunal impact on vegetation structure and ecosystem function in mangrove forests: a review. Aquatic Botany, v. 89, n. 2, p. 186-200, 2008.

COElHO Dos SANTOS, M. A.; COELHO, P. A. Crustacea Decapoda of the Paripe river estuary, Pernambuco, Brazil. Hydrobiologia, v. 449, n. 1/3, p. 77-79, 2001.

COLLING, L. A.; BEMVENUTI, C. E.; GANDRA, M S. Seasonal variability on the structure of sublittoral macrozoobenthic association in the Patos Lagoon estuary, southern Brazil. Iheringia, v. 97, n. 3, p. 257-262, 2007.

COLPO, K. D.; CHACUR, M. M.; GUIMARÃES, F. J.; NEGREIROS-FRANSOZO, M. L. Subtropical Brazilian mangroves as a refuge of crab (Decapoda: Brachyura) diversity. Biodivers. Conserv., v. 20, n. 13, p. 3239-3250, 2011.

CONDIE, S. A.; HAYES, D.; FULTON, E. A.; SAVINA, M. Modelling ecological change over half a century in a subtropical estuary: impacts of climate change, land-use, urbanization and freshwater extraction. Mar. Ecol. Progr. Ser., v. 457, p. 43-66, 2012.

CORBISIER, T. N. Benthic macrofauna of sandy intertidal zone at Santos estuarine system, São Paulo, Brazil. Bol. Inst. Oceanogr., v. 39, n. 1, p. 1-13, 1991.

DAY, J. W.; CHRISTIAN, R. R.; BOESCH, D. M.; YANEZARANCIBIA, A.; MORRIS, J.; TWILLEY, R. R.; NAYLOR, L.; SCHAFFNER, L.; STEVENSON, C. Consequences of climate change on the ecogeomorphology of coastal wetlands. Estuar. Coast., v. 31, p. 477-491, 2008. 
DEMOPOULOS, A. W. J.; FRY, B.; SMITH, C. R. Food web structure in exotic and native mangroves: a Hawaii-Puerto Rico comparison. Oecologia, v. 153, n. 3, p. 675-686, 2007.

DEMOPOULOS, A. W. J.; SMITH, C. R. Invasive mangroves alter macrofaunal community structure and facilitate opportunistic exotics. Mar. Ecol. Progr. Ser., v. 404, p. 5167, 2010.

DOLBETH, M.; CARDOSO, P. G.; GRILO, T. F.; BORDALO, M. D.; RAFAELLI, D.; PARDAL, M. A. Long-term changes in production by estuarine macrobenthos affected by multiple stressors. Estuar. Coast. Shelf Sci., v. 92, n. 1, p. 10-18, 2011.

DOMINGUEZ, J. M. L. The coastal zone of Brazil: an overview. J. Coatal Res., v. 1, n. 39, p. 16-20, 2006.

DONATO, D. C.; KAUFFMAN, J. B.; MURDIYARSO, D.; KURNIANTO, S.; STIDHAM, M.; KANNINEN, M. Mangroves among the most carbon-rich forests in the tropics. Nature Geoscience, v. 4, p. 293-297, 2011.

DONEY, S. C.; RUCKELSHAUS, M.; DUFFY, J. E.; BARRY, J. P.; CHAN, F.; ENGLISH, C. A.; GALINDO, H. M.; GREBMEIER, J. M.; HOLLOWED, A. B.; KNOWLTON, N.; POLOVINA, J.; RABALAIS, N. N.; SYDEMAN, W. J.; TALLEY, L. D. Climate change impacts on marine ecosystems. Ann. Rev. Mar. Sci., v. 4, p. 1-37, 2012.

DUARTE, C. M.; MIDDELBURG, J. J.; CARACO, N. Major role of marine vegetation on the oceanic carbon cycle. Biogeosciences, v. 2, p. 1-8, 2005.

EDGAR, G. J.; BARRETT, N. S. Benthic macrofauna in Tasmanian estuaries: scales of distribution and relationships with environmental variables. J. Exp. Mar. Biol. Ecol., v. 270, n. 1, p. 1-24, 2002.

ELLIOTT, M.; QUINTINO, V. The Estuarine Quality Paradox, Environmental Homeostasis and the difficulty of detecting anthropogenic stress in naturally stressed areas. Mar. Pollut. Bull., v. 54, n. 6, p. 640-645, 2007.

ELLIOTT, M.; WHITFIELD, A. K. Challenging paradigms in estuarine ecology and management. Estuar. Coast. Shelf Sci., v. 94, n. 4, p. 306-314, 2011.

FARACO, L. F. D.; LANA, P. C. Response of polychaetes to oil spills in natural and defaunated subtropical mangrove sediments from Paranaguá bay (SE Brazil). Hydrobiologia, v. 496, n. 1/3, p. 321-328, 2003.

FARACO, L. F. D.; LANA, P. C. Macrobenthic recolonization processes in mangroves of southern Brazil. J. Coatal Res., v. 39, n. 39, p. 1853-1858, 2004.

FARRAPEIRA, C. M. R.; RAMOS, C. A. C.; BARBOSA, D. F.; DE MELO, A. V. O. M.; PINTO, S. L.; VERÇOSA, M. M.; OLIVEIRA, D. A. S.; FRANCISCO, J. A. Zonación vertical del macrobentos de substratos sólidos del estuario del río Massangana, Bahía de Suape, Pernambuco, Brasil. Biota Neotrop., v. 9, n. 1, p. 87-100, 2009.

FERREIRA, J. G.; ANDERSEN, J. H.; BORJA, A.; BRICKER, S. B.; CAMP, J.; SILVA, M. C.; GARCÉS, E.; HEISKANEN, A. S; HUMBORG, C.; IGNATIADES, L.; LANCELOT, C.; MENESGUEN, A.; TETT, P.; HOEPFFNER, N.; CLAUSSEN, U. Overview of eutrophication indicators to assess environmental status within the European Marine Strategy Framework Directive. Estuar. Coast. Shelf Sci., v. 93, n. 2, p. 117-131, 2011.

FONSECA, G.; NETTO, S. A. Shallow sublittoral benthic communties of the Laguna Estuarine System, South Brazil. Braz. J. Oceanogr., v. 54, n. 1, p. 41-54, 2006.
FUJII, T. (2007). Spatial patterns of benthic macrofauna in relation to environmental variables in an intertidal habitat in the Humber estuary, UK: Developing a tool for estuarine shoreline management. Estuarine, Coastal and Shelf Science, 75(1-2), 101-119. doi:http://dx.doi.org/10.1016/j. ecss.2007.02.027

GARCÍA-RODRÍGUEZ， F., BRUGNOLI, E., MUNIZ, P., VENTURINI, N., BURONE, L., HUTTON, M., RODRIGUEZ, M., PITA, A., KANDRATAVICIUS, N., PAEREZ, L., VEROCAI, L. Warm-phase ENSO events modulate the continental freshwater input and the trophic state of sediments in a large South American estuary. Mar and Fresh Res 65 (1), 1-11, 2014

GERN, F. R.; LANA, P. C. Reciprocal experimental transplantations to assess effects of organic enrichment on the colonization of benthic macrofauna in a subtropical estuary. Mar. Pollut. Bull., v. 67, n. 1/2, p. 107-120, 2013.

GILLANDERS, B. M.; KINGSFORD, M. J. Impact of changes in flow of freshwater on estuarine and open coastal habitats and the associated organisms. Oceanogr. Mar. Biol. Ann. Rev., v. 40, p. 233-309, 2002.

HEIP, C. H. R.; GOOSEN, K. N.; HERMAN, P. M. J.; KROMKAMP, J. C.; MIDDELBURG, J. J.; SOETAERT, $\mathrm{K}$. Production and consumption of biological particles in temperate tidal estuaries. Oceanogr. Mar. Biol. Ann. Rev., v. 33, p. 1-149, 1995.

HEWITT, J. E.; THRUSH, S. F. Effective long-term ecological monitoring using spatially and temporally nested sampling. Environ. Monit. Assess., v. 133, n. 1/3, p. 295-307, 2007.

HEWITT, J. E.; THRUSH, S. F. Reconciling the influence of global climate phenomena on macrofaunal temporal dynamics at a variety of spatial scales. Glob. Chang. Biol., 15, n. 8, p. 1911-1929, 2009.

HIRST, A. J. (2004). Broad-scale environmental gradients among estuarine benthic macrofaunal assemblages of south-eastern Australia: implications for monitoring estuaries. Marine and Freshwater Research, 55(1), 79-92.

JOSEFSON, A. B., J. L. S. HANSEN 2004. Species richness of benthic macrofauna in Danish estuaries and coastal areas. Global Ecology and Biogeography 13(3):273-288.

JUNQUEIRA, A. O. R.; FALCÃO, A. P. C.; MAYER-PINTO, M.; VIANA, M. S.; SILVA, S. H. G. Spatial and temporal variations on intertidal barnacle abundance in a tropical bay. Nauplius, v. 8, n. 2, p. 195-204, 2000.

$\mathrm{KOCH}, \mathrm{V}$;; WOLFF, M. Energy budget and ecological role of mangrove epibenthos in the Caeté estuary, North Brazil. Mar. Ecol. Progr. Ser., v. 228, p. 119-130, 2002.

KOTTA, J.; KOTTA, I.; SIMM, M.; PÕLLUPÜÜ, M. Separate and interactive effects of eutrophication and climate variables on the ecosystem elements of the Gulf of Riga. Estuar. Coast. Shelf Sci., v. 84, n. 4, p. 509-518, 2009.

KRISTENSEN, E.; BOUILLON, S.; DITTMAR, T.; MARCHAND, C. Organic carbon dynamics in mangrove ecosystems: a review. Aquatic Botany, v. 89, p. n. 2, 201-219, 2008.

KRULL, M.; ABESSA, D. M. S.; HATJE, V.; BARROS, F. Integrated assessment of metal contamination in sediments from two tropical estuaries. Ecotoxicol. Environ. Saf., v. 106, p. 195-203, 2014.

LANA, P. C. Macrofauna bêntica de fundos sublitorais não consolidados da Baía de Paranaguá (Paraná). Nerítica, v. 1, n. 3, p. 79-89, 1986b. 
LANA, P. C.; CAMARGO, M. G.; BROGIM, R. A.; ISAAC, V. J. O Bentos da Costa Brasileira: avaliação crítica e levantamento. Rio de Janeiro: FEMAR, 1996. 431p.

LANA, P. C.; COUTO, E. C. G.; OLIVEIRA, M. V. O. Polychaete distribution and abundance in intertidal flats of Paranaguá Bay (Brazil). Bull. Mar. Sci., v. 60, n. 2, p. 433-442, 1997.

LANA, P. C.; GUISS, C. Influence of Spartina alterniflora on structure and temporal variability of macrobenthic associations in a tidal flat of Paranaguá Bay (southeastern Brazil). Mar. Ecol. Progr. Ser., v. 73, p. 231-244, 1991.

LANA, P. C.; GUISS, C. Macrofauna-plant biomass interactions in a euhaline salt marsh in Paranagua Bay SE Brazil. Mar. Ecol. Progr. Ser., v. 80, p. 57-64, 1992.

LAVRADO, H. P.; FALCÃO, A. P. C.; CARVALHO-CUNHA, P.; SILVA, S. H. G. Composition and distribution of Decapoda from Guanabara Bay, RJ. Nauplius, v. 8, n. 1, p. 15-23, 2000.

LEE, S. Y. Ecological role of graspid crabs in mangrove ecosystems: a review. Mar. Fresh. Res., v. 49, p. 335-343, 1998.

LEVIN, S. A. The problem of pattern and scale in ecology. Ecology, v. 73, p. 1943-1967, 1992.

MAGALHÃES, W. F.; BARROS, F. Structural and functional approaches to describe polychaete assemblages: ecological implications for estuarine ecosystems. Mar. Fresh. Res., v. 62, n. 8, p. 918-926, 2011.

MALLIN, M. A.; PAERL, H. W.; RUDEK, J.; BATES, P. W. Regulation of estuarine primary production by watershed rainfall and river flow. Mar. Fresh. Res., v. 93, p. 199-203, 1993.

MARENGO, J. A.; AMBRIZZI, T.; ROCHA, R. P.; ALVES, L. M.; CUADRA, S. V.; VALVERDE, M. C.; TORRES, R. R.; SANTOS, D. C.; FERRAZ, S. E. T. Future change of climate in South America in the late twenty-first century: intercomparison of scenarios from three regional climate models. Clim. Dyn., v. 35, p. 1073-1097, 2010.

MASUNARI, S. Distribuição e abundância dos caranguejos Uca, Leach (Crustacea, Decapoda, Ocypodidae) na Baía de Guaratuba, Paraná, Brasil. Rev. Bras. Zool., v. 23, n. 4, p. 901-914, 2006.

MCLEOD, E.; CHMURA, G. L.; BOUILLON, S.; SALM, R.; BJÖRK, M.; DUARTE, C. M.; LOVELOCK, C. E.; SCHLESINGER, W. H.; SILLIMAN, B. R. A blueprint for blue carbon: toward an improved understanding of the role of vegetated coastal habitats in sequestering CO2. Front. Ecol. Environ., v. 9, n. 10, p. 552-560, 2011.

MENDES, C. L. T.; SOARES-GOMES, A. Macrobenthic community structure in a Brazilian choked lagoon system under environmental stress. Zoologia, v. 28, n. 3, p. 365-378, 2011.

MERRIFIELD, M. S.; HINES, E.; LIU, X.; BECK, M. W. Building regional threat-based networks for estuaries in the Western United States. PLOS One, v. 6, n. 2, p. e17407, 2011.

MEURER, A. Z.; NETTO, S. A. Seasonal dynamics of bentic communities in a shallow sublittoral site of Laguna Estuarine System (South Brazil). Braz. J. Aquat. Sci. Technol., v. 11, n. 2, p. 53-62, 2007.

MILLIMAN, J. D.; FARNSWORTH, K. L.; JONES, P. D.; XU, K. H.; SMITH, L. C. Climatic and anthropogenic factors affecting river discharge to the global ocean, 1951-2000. Glob. Planet. Chang.,v. 62, n. 3/4, p. 187-194, 2008.
MONTAGNA, P., \& KALKE, R. (1992). The effect of freshwater inflow on meiofaunal and macrofaunal populations in the Guadalupe and Nueces Estuaries, Texas. Estuaries, 15(3), 307-326.

MORRISEY, D. J., TURNER, S. J., MILLS, G. N., BRUCE WILLIAMSON, R., \& WISE, B. E. (2003). Factors affecting the distribution of benthic macrofauna in estuaries contaminated by urban runoff. Mar. Pollut. Bull., v. 37, n. 3/7, p. 261-279.

MORTIMER, R. J. G., KROM, M. D., WATSON, P. G., FRICKERS, P. E., DAVEY, J. T., \& CLIFTON, R. J. (1999). Sediment-Water Exchange of Nutrients in the Intertidal Zone of the Humber Estuary, UK. Mart. Pollut. Bull., 37(3-7), 261279.

MUNIZ, P.; VENTURINI, N.; PIRES-VANIN, A. M. S.; TOMMASI, L. R.; BORJA, A. Testing the applicability of a Marine Biotic Index (AMBI) to assessing the ecological quality of soft-bottom benthic communities in the South America Atlantic region. Mar. Pollut. Bull., v. 50, n. 6, p. 624-637, 2005.

NAJJAR, R. G.; WALKER, H. A.; ANDERSON, P. J.; BARRON, E. J.; BORD, R. J.; GIBSON, J. R.; KENNEDY, V. S.; KNIGHT, C. G.; MEGONIGAL, J. P.; O'CONNOR, R. E.; POLSKY, C. D.; PSUTY, N. P.; RICHARDS, B. A.; SORENSON, L. G.; STEELE, E. M.; SWANSON, R. S. The potential impacts of climate change on the mid-Atlantic coastal region. Clim. Res., v. 14, p. 219-233, 2000.

NALESSO, R. C.; JOYEUX, J. C.; QUINTANA, C. O.; TOREZANI, E.; OTEGUI, A. C. P. Soft-Bottom macrobenthic communities of the Vitória Bay estuarine system, Southeastern Brazil. Braz. J. Oceanogr., v. 53, n. 1/2, p. 23-38, 2005 .

NEIRA, C.; LEVIN, L. A.; GROSHOLZ, E. D. Benthic macrofaunal communities of three sites in San Francisco Bay invaded by hybrid Spartina, with comparison to uninvaded habitats. Mar. Ecol. Progr. Ser., v. 292, p. 111-126, 2005.

NETTO, S. A.; GALLUCCI, F. Meiofauna and macrofauna communities in a mangrove from the Island of Santa Catarina, South Brazil. Hydrobiologia, v. 505, p. 159-170, 2003.

NETTO, S. A.; LANA, P. C. Effects of sediment disturbance on the structure of benthic fauna in a subtropical tidal creek of southeastern Brazil. Mar. Ecol. Progr. Ser., v. 106, p. 239-247, 1994.

NETTO, S. A.; LANA, P. C. Intertidal zonation of benthic macrofauna in a subtropical salt marsh and nearby unvegetated flat (SE, Brazil). Hydrobiologia, v. 353, n. 1/3, p. 171-180, 1997.

NETTO, S. A.; LANA, P. C. The role of above- and belowground components of Spartina alterniflora (Loisel) and detritus biomass in structuring macrobenthic associations of Paranaguá Bay (SE, Brazil). Hydrobiologia, v. 400, p. 167177, 1999.

NICHOLLS, R. J.; CAZENAVE, A. Sea-level rise and its impact on coastal zones. Science, v. 328, p. 1517-1520, 2010.

NILSSON, H.C., Rosenberg, R. (2000) Succession in marine benthic habitats and fauna in response to oxygen deficiency: analysed by sediment profile-imaging and by grab samples. Marine Ecology-Progress Series, 197, 139-149 
NORKKO, A.; THRUSH, S. F.; HEWITT, J. E.; CUMMINGS, V. J.; NORKKO, J.; ELLIS, J. I.; FUNNELL, G. A.; SCHULTZ, D.; MACDONALD, I. Smothering of estuarine sandflats by terrigenous clay: the role of wind-wave disturbance and bioturbation in site-dependent macrofaunal recovery. Mar. Ecol. Progr. Ser., v. 234, p. 23-41, 2002.

OMENA, E. P.; LAVRADO, H. P.; PARANHOS, R.; SILVA, T. A. Spatial distribution of intertidal sandy beach polychaeta along an estuarine and morphodynamic gradient in an eutrophic tropical bay. Mar. Pollut. Bull., v. 64, n. 9, p. 18611873, 2012.

OSHIRO, L. M. Y.; SILVA, R.; SILVA, Z. S. Composição da fauna de braquiúros (Crustacea Decapoda) dos manguezais da Baía de Sepetiba-RJ. Nauplius, v. 6, p. 31-40, 1998.

OURIVES, T. M.; RIZZO, A. E.; BOEHS, G. Composition and spatial distribution of the benthic macrofauna in the Cachoeira River estuary, Ilhéus, Bahia, Brazil. Rev. Biol. Mar. Oceanogr., v. 46, n. 1, p. 17-25, 2011.

PAGLIOSA, P. R.; BARBOSA, F. A. R. Assessing the environment-benthic fauna coupling in protected and urban areas of Southern Brazil. Biol. Conserv., v. 129, n. 3, p. 408417, 2006.

PAGLIOSA, P. R.; LANA, P. C. Population dynamics and secondary production of NEREIS OLIGOHALINA (NEREIDIDAE: POLYCHAETA) from a subtropical marsh in southeast Brazil. Bull. Mar. Sci., v. 67, n. 1, p. 259-268, 2000 .

PAGLIOSA, P. R.; LANA, P. C. Impact of plant cover removal on macrobenthic community structure of a subtropical salt marsh. Bull. Mar. Sci., v. 77, n. 1, p. 1-17, 2005.

PAIXÃO, J. F.; OLIVEIRA, O. M. C.; DOMINGUEZ, J. M. L.; ALMEIDA, E. S.; CARVALHO, G. C.; MAGALHÃES, W. F. Integrated assessment of mangrove sediments in the Camamu Bay (Bahia, Brazil). Ecotoxicol. Environ. Saf., v. 74, n. 3, p. 403-415, 2011.

PARLIAMENT, E. Water Framework Directive: Directive 2000/60/EC of the European Parliament and of the Council of 23 October 2000 establishing a framework for the community action in the field of water policy. COMMISSION, E. Official Journal of European Communities, 2000.

PENDLETON, L.; DONATO, D. C.; MURRAY, B. C.; CROOKS, S.; JENKINS, W. A.; SIFLEET, S.; CRAFT, C.; FOURQUREAN, J. W.; KAUFFMAN, J. B.; MARBA, N.; MEGONIGAL, P.; PIDGEON, E.; HERR, D.; GORDON, D.; BALDERA, A. Estimating global "Blue Carbon" emissions from conversion and degradation of vegetated coastal ecosystems. PLOS One, v. 7, n. 9, p. e43542, 2012.

QUinTINO, V.; ELliOTT, M.; RODRIGUES, A. M. The derivation, performance and role of univariate and multivariate indicators of benthic change: case studies at differing spatial scales. J. Exp. Mar. Biol. Ecol., v. 330, n. 1, p. 368-382, 2006.

RODRIGUES, A. M.; QUINTINO, V.; SAMPAIO, L.; FREITAS, R.; NEVES, R. Benthic biodiversity patterns in Ria de Aveiro, Western Portugal: Environmental-biological relationships. Estuar. Coast. Shelf Sci., v. 95, n. 2/5, p. 338-348, 2011.

RONDINELLI, S. F.; BARROS, F. Evaluating shellfish gathering (Lucina pectinata) in a tropical mangrove system. J. Sea Res., v. 64 , n. 3, p. $401-407,2010$.
ROSA FILHO, J. S.; BUSMAN, D. V.; VIANA, A. P.; GREGÓRIO, A. M.; OLIVEIRA, D. M. Macrofauna bentônica de zonas entre-marés não vegetadas do estuário do rio Caeté, Bragança, Pará. Bol. Mus. Para. Emilio Goeldi Cienc. Nat., v. 4, n. 1, p. 85-96, 2006.

ROSA, L. C.; BEMVENUTI, C. E. Infaunal recruitment patterns in soft bottom habitats of the Patos Lagoon estuary, southern Brazil: influence of Chasmagnathus granulata (Brachyura, Grapsidae) disturbance. Inheringia, v. 94, n. 3, p. 301-305, 2004.

ROSA, L. C.; BEMVENUTI, C. E. Seria a macrofauna bentônica de fundos não consolidados influenciada pelo aumento na complexidade estrutural do habitat? O caso do estuário da lagoa dos patos. Braz. J. Aquat. Sci. Technol., v. 11, n. 1, p. 51-56, 2007.

ROSENBERG, R. (1977). Benthic macrofaunal dynamics, production, and dispersion in an oxygen-deficient estuary of west Sweden. Journal of Experimental Marine Biology and Ecology, 26(2), 107-133. doi:http://dx.doi.org/10.1016/00220981(77)90102-2

SANTI, L.; TAVARES, M. Polychaete assemblage of an impacted estuary, Guanabara Bay, Rio de Janeiro, Brazil. Braz. J. Oceanogr., v. 57, n. 4, p. 287-303, 2009.

SCAVIA, D.; FIELD, J. C.; BOESCH, D. F.; BUDDEMEIER, R. W.; BURKETT, V.; CAYAN, D. R.; FOGARTY, M.; HARWELL, M. A.; HOWARTH, R. W.; MASON, C.; REED, D. J.; ROYER, T. C.; SALLENGER, A. H.; TITUS, J. G. Climate change impacts on U.S. Coastal and Marine Ecosystems. Estuaries, v. 25, n. 2, p. 149-164, 2002.

SCHNEIDER, D. C. The rise of the concept scale in ecology. BioScience, v. 51, n. 7, p. 545-553, 2001.

SCHNEIDER, M.; SCHOLZ, J.; LUBELL, M.; MINDRUTA, D.; EDWARDSEN, M. Building consensual institutions: networks and the National Estuary Program. Am. J. Pol. Sci., v. 47, n. 1, p. 143-158, 2003.

SEMENIUK, V. Predicted response of coastal wetlands to climate changes: a Western Australian model. Hydrobiologia, v. 708, n. 1, p. 23-43, 2013.

SHORT, F. T.; NECKLES, H. A. The effects of global climate change on seagrasses. Aquatic Botany, v. 63, n. 3/4, p. 169196, 1999.

SMITH, C. R.; AUSTEN, M. C.; BOUCHER, G.; HEIP, C.; HUTCHINGS, P. A.; KING, G. M.; KOIKE, I.; LAMBSHEAD, P. J. D.; SNELGROVE, P. V. R. Global change and biodiversity linkages across the sediment-water interface. BioScience, v. 50, n. 12, p. 1108-1120, 2000.

SOARES, H. C.; GHERARDI, D. F. M.; PEZZI, L. P.; KAYANO, M. T.; PAES, E. T. Patterns of interannual climate variability in large marine ecosystems. J. Mar. Syst., v. 134, p. 57-68, 2014.

SOARES, R.; PEIXOTO, S.; BEMVENUTI, C. E.; WASIELESKY, W.; D'INCAO, D.; MURCIA, N.; SUITA, S. Composition and abundance of invertebrate benthic fauna in Farfantepenaeus paulensis culture pens (Patos Lagoon estuary, Southern Brazil). Aquaculture, v. 239, p. 199-215, 2004.

SOARES-GOMES, A.; MENDES, C. L. T.; TAVARES, M.; SANTI, L. Taxonomic sufficiency of polychaete taxocenes for estuary monitoring. Ecol. Indic., v. 15, n. 1, p. 149-156, 2012 . 
SOUZA, F. M.; BRAUKO, K. M.; LANA, P. C.; MUNIZ, P.; CAMARGO, M. G. The effect of urban sewage on benthic macrofauna: a multiple spatial scale approach. Mar. Pollut. Bull., v. 67, n. 1/1, p. 234-240, 2013.

SUNDERLAND, T.; SUNDERLAND-GROVES, J.; SHANLEY, P.; CAMPBELL, B. Bridging the gap: how can information access and exchange between conservation biologists and field practitioners be improved for better conservation outcomes? Biotropica, v. 41, n. 5, p. 549-554, 2009.

SWEETMAN, A. K.; MIDDELBURG, J. J.; BERLE, A. M.; BERNARDINO, A. F.; SCHANDER, C.; DEMOPOULOS, A. W. J.; SMITH, C. R. Impacts of exotic mangrove forests and mangrove deforestation on carbon remineralization and ecosystem functioning in marine sediments. Biogeosciences, v. 7, p. 2129-2145, 2010.

TABARELLI, M.; ROCHA, C. F. D.; ROMANOWSKI, H. P.; ROCHA, O.; LACERDA, L. D. PELD-CNPq. Dez anos do programa de pesquisas ecológicas de longa duração no Brasil: achados, lições e perspectivas. Recife: Editora Universitária, 2013.

TARARAM, A. S.; WAKABARA, Y. Benthic fauna living on Spartina alterniflora of Cananéia estuarine region $\left(25^{\circ} 02^{\prime} \mathrm{S}\right.$ 4756 'W). Bol. Inst. Oceanogr., v. 35, n. 2, p. 103-113, 1987.

THURMAN, C.; HANNA, J.; BENNETT, C. Ecophenotypic physiology: osmoregulation by fiddler crabs (Uca spp.) from the northern Caribbean in relation to ecological distribution.

Mar. Freshw. Behav. Physiol., v. 43, n. 5, p. 339-356, 2010.

TOMMASI, L. R. Observações sobre a fauna bêntica do complexo estuarino-lagunar de Cananéia (SP). Bol. Inst. Oceanogr., v. 19, p. 43-56, 1970.
TURRA, A.; CRÓQUER, A.; CARRANZA, A.; MANSILLA, A.; ARECES, A. J.; WERLINGER, C.; MARTÍNEZ-BAYÓN, C.; NASSAR, C. A.; PLASTINO, E.; SCHWINDT. E.; SCARABINO, F.; CHOW, F.; FIGUEROA, F. L.; BERCHEZ, F.; HALL-SPENCER, J. M.; SOTO, L. A.; BUCKERIDGE, M. S.; COPERTINO, M. S,; SZÉCHY, M. T.; GHILARDILOPES, N. P.; HORTA, P; COUTINHO. R; FRASCHETTI, S; LEÃO, Z. M. Global environmental changes: setting priorities for Latin American coastal habitats. Glob. Chang. Biol., v. 19, n. 7, p. 1965-1969, 2013.

VALENÇA, A. P. M. C.; SANTOS, P. J. P. Macrobenthic community for assessment of estuarine health in tropical areas (NE Brazil): review of macrofauna classification in ecological groups and application of AZTI Marine Biotic Index. Mar. Pollut. Bull., v. 64, n. 9, p. 1809-1820, 2012.

VAROLI, F. M. F. Avaliação da macrofauna bentônica da zona entre-marés em dois baixios do sistema estuarino-lagunar de Iguape-Cananéia. BIOIKOS, v. 4, n. 2, p. 24-39, 1990.

VILAR, C. C.; JOYEUX, J.; GIARRIZZO, T.; SPACH, H. L.; VIEIRA, J. P.; VASKE-JUNIOR, T. Local and regional ecological drivers of fish assemblages in Brazilian estuaries. Mar. Ecol. Progr. Ser., v. 485, p. 181-197, 2013.

WHITFIELD, A. K.; ELLIOTT, M.; BASSET, A.; BLABER, S. J. M.; WEST, R. J. Paradigms in estuarine ecology - A review of the Remane diagram with a suggested revised model for estuaries. Estuar. Coast. Shelf Sci., v. 97, p. 78-90, 2012.

ZALMON, I. R.; KROHLING, W.; FERREIRA, C. E. L. Abundance and diversity patterns of the sessile macrobenthic community associated with environmental gradients in Vitória Harbor, southeastern Brazil. Zoologia, v. 28, n. 5, p. 641-652, 2011. 
